\title{
Vähentääkö rauta- tai alumiinisulfaatti liukoisen fosforin huuhtoumista korkean fosforitilan mailta? Testaus pintavaluntasimulaattorin (SIMU) avulla
}

Kirsi Järvenranta, Mari Räty ja Perttu Virkajärvi

MTT, Kotieläintuotannon tutkimus, Halolantie 31A, 71750 Maaninka, sähköposti: etunimi.sukunimi@mtt.fi

\section{TIIVISTELMÄ}

Tässä työssä tutkittiin rauta- ja alumiinisulfaatin vaikutusta P kuormituksen vähentämisessä korkean P-tilan nurmilta käsittelemättömään kontrolliin verrattuna. Tutkimuksessa käytettiin pintavaluntasimulaattoria.

Koe suoritettiin MTT Maanigalla vuosina 2010-2011. Kojäseniä oli kolme ja kerranteita neljä: 1) kontrolli, 2) ALG $\left(\mathrm{Al}_{2}\left(\mathrm{SO}_{4}\right)_{3}\right)$ ja 3) Ferix-3 $\left(\mathrm{Fe}_{2}\left(\mathrm{SO}_{4}\right)_{3} * \mathrm{nH}_{2} \mathrm{O}\right.$. Käsittelyannos oli $500 \mathrm{~kg} / \mathrm{ha}$ kemikaalia ja liuos annosteltiin kastelukannulla koeruuduille. Viiden senttimetrin paksuiset nurmilaatat nostettiin syksyllä 2010 ja laattojen läheisyydestä otettiin maa- ja kasvustonäytteet, joista analysoitiin ravinnepitoisuudet. Sulatuskokeessa nurmilaatat nostettiin SIMU laitteiden päälle ja niiden pintaan lisättiin lumi. Lumi sulatettiin infrapunalämmittimillä 7 päivän aikana. Sulamisvedet kerättiin ja niistä analysoitiin kokonais- ja liuennut fosfori sekä kokonais-, ammonium- ja nitraattityppi. Sulatusprosessi toistettiin kevään aikana kolme kertaa kullekin laatalle.

Koealueen maaperän vesi - ja helppoliukoisen fosforin pitoisuus oli korkea. Käsittelyt eivät vaikuttaneet maaperän P-pitoisuuteen. Käsittelyt eivät myöskään vahingoittaneet kasvustoa, vaikka liuoksen $\mathrm{pH}$ oli alhainen, eivätkä vaikuttaneet nurmen P-pitoisuuksiin kumpanakaan vuonna. Sen sijaan sekä ALG että Ferix-3 vähensivät kontrolliin verrattuna selvästi sekä kokonais- että liukoisen fosforin huuhtoutumista ensimmäisen vuoden aikana kaikilla sulatusjaksoilla, mutta eivät enää seuraavana vuonna. Ensimmäisen vuoden kaikissa sulatusjaksoissa valumaveden rikkipitoisuus oli ALG ja Ferix-3 käsittelyissä korkeampi kuin kontrollissa ja vaikutus on suurin ensimmäisellä jaksolla Toisena vuonna valumaveden rikkipitoisuudessa ei ollut eroja käsittelyiden välillä. Valumaveden rauta ja alumiinipitoisuudet olivat alhaiset molempina vuosina. Kemikaalikäsittelyt alensivat valumaveden pH:ta ensimmäisenä vuonna 0.1 yksikköä. Toisena vuonna käsittelyillä ei ollut eroja.

Kemikaalit toimivat ensimmäisenä vuonna tehokkaasti: reduktio-\% kontrolliin verrattuna ALGruuduilla 56-70 \% ja Ferix-3 ruuduilla 29-56 \%, mutta vaikutus oli lyhytaikainen. Toisaalta myös käytetty annos oli pieni. Veden puhdistamiseen käytettävät alumiini- ja rautapohjaiset kemikaalit näyttävät olevan potentiaalinen keino liukoisen fosforin huuhtouman vähentämisessä lyhytaikaisesti rajoitetuilla alueilla.

Asiasanat: nurmi, fosfori, huuhtoutuminen, simulointi 


\section{Johdanto}

Suomessa valtaosa nurmituotannosta sijaitsee alueilla, joilla on lumiset talviolosuhteet ja jopa $80 \%$ vuosittaisesta pintavalunnasta ja fosforikuormituksesta saattaa kertyä keväällä muutaman viikon aikana lumien sulaessa (Saarijärvi ja Virkajärvi 2004). Nurmiviljelyssä eroosio on tunnetusti vähäistä, mutta silti nurmilta on koeolosuhteissa mitattu huuhtoutuvan huomattavia määriä fosforia (1-2 $\mathrm{kg} / \mathrm{ha} / \mathrm{v}$ ) pintavalunnan mukana. Tästä liukoisen, leville käyttökelpoisena pidetyn fosforin osuus on jopa 80-95 \% (Turtola ja Kemppainen 1998, Saarijärvi ja Virkajärvi 2004). Maan ja kasvuston jäätymis- ja sulamissyklit lisäävät liukoisen fosforin huuhtoutumista (Uusi-Kämppä ja Jauhiainen 2010). Nurmivuosina laidunnus, pintaan annettu fosforilannoitus ja pintaan levitettävä lietelanta johtavat maan fosforipitoisuuden nousuun ja sitä kautta pintavalunnan fosforipitoisuuden kasvuun (Uusi-Kämppä ym. 2012, Saarijärvi ja Virkajärvi 2004).

Liukoisen fosforin huuhtoutumista korkean P-tilan mailta pitää saada vähennettyä ja fosforia sitovat kemikaalit voivat tarjota tähän yhden ratkaisun. Kemiallisia käsittelyitä fosforihuuhtouman vähentämiseksi on testattu aiemmin useissa kokeissa, joissa on selvitetty lietteeseen tai suoraan maahan sekoitettujen fosforia sitovien tai flokkuloivien aineiden vaikutusta (mm. Uusi-Kämppä ym. 2012, Brennan ym. 2011, Torbert ym. 2005). Tämän työn tarkoituksena oli verrata kahden fosforia sitovan kemikaalin: rautasulfaatin ja alumiinisulfaatin vaikutusta $\mathrm{P}$ kuormituksen vähentämisessä korkean P-tilan nurmilta. Tutkimuksessa käytettiin uutta menetelmää: pintavaluntasimulaattoria (SIMU; Saarijärvi ja Virkajärvi 2010).

\section{Aineisto ja menetelmät}

Koe suoritettiin MTT Maanigalla vuosina 2010-2011. Pintamaassa karkean hiedan osuus oli 37 \% ja hienon hiedan $31 \%$. Savipitoisuus on alhainen (7 \%). Koealueen nurmi (timotei-nurminata) perustettiin 2008 ja lannoitettiin vuosittain $160 \mathrm{~N}$, 9 P, ja $73 \mathrm{~K} \mathrm{~kg} / \mathrm{ha}$. Säätiedot saatiin Ilmatieteenlaitoksen viralliselta sääasemalta. Pitkänajan (1971-2000) sadannan keskiarvo alueella on $609 \mathrm{~mm}$ ja vuoden keskilämpötila $2.8^{\circ} \mathrm{C}$.

Kokeen malli oli satunnaistettu täydellisten lohkojen koe, koejäsenet: 1) kontrolli, 2) ALG $\left(\mathrm{Al}_{2}\left(\mathrm{SO}_{4}\right)_{3}\right)$ ja 3) Ferix-3 $\left(\mathrm{Fe}_{2}\left(\mathrm{SO}_{4}\right)_{3} * \mathrm{nH}_{2} \mathrm{O}\right)$. Kaikissa käsittelyissä oli neljä toistoa. Käsittelyannos oli 50 g kemikaalia/m² (500 kg/ha). Määrä vastaa 9 g Al / m² (90 kg Al / ha) ja 10 g Fe / m² (100 kg Fe / ha). Kemikaalit liuotettiin veteen suhteessa 7,5 g kemikaalia / l vettä. Rakeiden vesiliukoisuus oli > 99 \% ja valmiit liuokset olivat happamia: ALG -liuoksen $\mathrm{pH}$ oli 3.32 ja Ferix-3 liuoksen 1,99. Liuos annosteltiin kastelukannulla koeruuduille 4.10.2010.

Nurmilaatat (koko 0,33 x 0,90 m, paksuus $5 \mathrm{~cm}$ ) nostettiin 20.10.2010. Laattojen välittömästä läheisyydestä otettiin maanäyte 0-5 cm, josta analysoitiin helppoliukoiset $\mathrm{P}, \mathrm{Ca}, \mathrm{Mg}, \mathrm{K}, \mathrm{Na}, \mathrm{S}$ ja $\mathrm{Cl}$ ja pH (Vuorinen \& Mäkitie 1955) sekä vesiliukoinen $\mathrm{P}$ ( $\mathrm{P}_{\mathrm{H} 2 \mathrm{O}}$; uuttosuhde1:150; Saarela 1992;). Kasvustonäytteet otettiin 8.11.2010 maanpintaan $30 \mathrm{~cm} * 30 \mathrm{~cm}$ alueelta laatan vierestä ja niistä analysoitiin kuiva-ainesato sekä kasvuston N-pitoisuus kuivapolttomenetelmällä (Leco). Märkäpoltetuista kasvinäytteistä analysoitiin $\mathrm{Ca}, \mathrm{Mg}, \mathrm{K}, \mathrm{P}, \mathrm{S}$ ja $\mathrm{Na}$ pitoisuudet (Huang ja Schulte 1985) ICP-OES:Ilä. Käsittelyitä ei toistettu vuonna 2011, vaan edellisenä vuonna käsitellyiltä ruuduilta nostettiin uudet laatat. Koeruudut niitettiin $7 \mathrm{~cm}$ sänkeen 28.7.2011 ja laatat nostettiin 7.11. Laattojen välittömästä läheisyydestä otettiin kasvusto - ja maanäyte (7.11.), joista tehtiin samat analyysit kuin vuotta aiemmin.

Maalaatat säilytettiin suojattuina ulkolämpötilassa kokeen alkuun saakka. Sulatuskokeessa jäätyneet nurmilaatat nostettiin SIMU laitteiden päälle ja niiden pintaan lisättiin kahdessa erässä yhteensä $30 \mathrm{~kg} /$ nurmilaatta lunta (vastaa n. $100 \mathrm{~mm}$ vettä). Simulaattorit sijaitsivat lämmittämättömässä hallissa. Lumi sulatettiin infrapunalämmittimillä 7 päivän aikana. Lämmittimet $(100 \mathrm{~cm}, 1000 \mathrm{~W})$ sijaitsivat noin $80 \mathrm{~cm}$ korkeudella lumen pinnasta ja lämmitys oli päällä keskimäärin 3 h 15 min päivittäin. Muun ajan lämpötila seurasi vapaasti ulkolämpötilaa. Kunkin sulatusjakson lopussa laatat siirrettiin suojattuina takaisin ulkovarastoon odottamaan seuraavaa sulatusjaksoa. Prosessi (jäädytys, lumetus ja sulatus) toistettiin kevään aikana kolme kertaa kullekin laatalle. Sulamisvedet kerättiin ja niistä analysoitiin $\mathrm{pH}$, kokonais- ja liuennut fosfori (suodatus $<0,2$ $\mu \mathrm{m})$ sekä S, Fe ja Al. Kokonaisfosfori määritettiin SFS 3026 standardin ja liukoinen fosfori SFS 3025 
standardin mukaan. Rikki, alumiini ja rauta määritettiin suodatetusta $(0,45 \mu \mathrm{m})$ näytteestä ICPOES:llä.

Tulokset analysoitiin tilastollisesti käyttäen SAS 9.2-ohjelmiston Mixed-proseduuria. Kiinteinä tekijöinä mallissa olivat maaperän ja rehun osalta kemikaalikäsittely ja vuosi ja näiden yhdysvaikutus. Satunnaistekijänä oli kerranne. Valumaveden osalta vuodet laskettiin erikseen ja kiinteinä tekijöinä olivat kemikaalikäsittely ja sulatusjakso ja näiden yhdysvaikutus. Satunnaistekijänä oli kerranne. pH:n osalta varianssianalyysi laskettiin $\mathrm{H}_{3} \mathrm{O}^{+}$-ionipitoisuudelle.

\section{Tulokset}

Käsittelyiden ja maalaattojen noston välisenä aikana vuonna 2010 sää oli alkuun melko lämmin, vuorokauden keskilämpötila ensimmäisten 10 vuorokauden aikana oli $6.1{ }^{\circ} \mathrm{C}$, minkä jälkeen sää kylmeni ja koko jakson keskilämpötila oli $3{ }^{\circ} \mathrm{C}$. Maanpinnassa kylmin mitattu lämpötila tällä jaksolla oli -9.8 ${ }^{\circ} \mathrm{C}$. Lämpösummaa kertyi 18 astetta ja jakson sademäärä oli 24 mm. Vuonna 2011 niiton ja maalaattojen noston välillä sää oli edellisvuotta leudompi. Maanpinnan minimilämpötila käväisi jakson aikana alimmillaan $-3.5{ }^{\circ} \mathrm{C}$ :ssa, ja koko jakson keskilämpötila oli $5.5^{\circ} \mathrm{C}$. Lämpösummaa kertyi 33 astetta ja sademäärä oli $43 \mathrm{~mm}$.

Koealueen maaperän ravinnepitoisuudet 2010-2011 on esitetty Taulukossa 1. Koealueen maaperän vesi - ja helppoliukoisen fosforin pitoisuus oli korkea ja käsittelyiden tai vuosien välillä ei ollut eroja. Ainoa ero käsittelyiden välinen ero löytyi ensimmäisenä vuonna maaperän rikkipitoisuudesta, jolloin ALG ja Ferix-3 ruutujen S-pitoisuus oli noin viisinkertainen kontrolliruutuihin verrattuna.

Taulukko 1. Kemiallisten käsittelyjen vaikutus koeruutujen maaperän pH:n, vesiliukoisen fosforin $\left(\mathrm{P}_{\mathrm{H} 2 \mathrm{O}}\right)$ sekä helppoliukoisten ravinteiden pitoisuuksiin 2010-2011.

\begin{tabular}{|c|c|c|c|c|c|c|c|c|c|}
\hline & $\mathrm{pH}$ & $\begin{array}{l}\mathrm{P}_{\mathrm{H} 2 \mathrm{O}} \\
\mathrm{mg} / \mathrm{kg}^{1)}\end{array}$ & $\begin{array}{l}\mathrm{P} \\
\mathrm{mg} / \mathrm{l}\end{array}$ & $\begin{array}{l}\mathrm{Ca} \\
\mathrm{mg} / \mathrm{l}\end{array}$ & $\begin{array}{l}\mathrm{K} \\
\mathrm{mg} / \mathrm{l}\end{array}$ & $\begin{array}{l}\mathrm{Mg} \\
\mathrm{mg} / \mathrm{l}\end{array}$ & $\begin{array}{l}\mathrm{S} \\
\mathrm{mg} / \mathrm{l}\end{array}$ & $\begin{array}{l}\mathrm{Na} \\
\mathrm{mg} / \mathrm{l}\end{array}$ & $\begin{array}{l}\mathrm{Cl} \\
\mathrm{mg} / \mathrm{l}\end{array}$ \\
\hline \multicolumn{10}{|l|}{2010} \\
\hline Kontrolli & 6,8 & 34 & 57 & 2450 & 138 & 131 & 9,8 & 9,9 & 8,8 \\
\hline $\mathrm{ALG}^{2)}$ & 6,6 & 29 & 48 & 2140 & 125 & 131 & 54 & 11 & 7,8 \\
\hline Ferix-3 $3^{3)}$ & 6,7 & 31 & 51 & 2470 & 125 & 128 & 51 & 9,7 & 9,9 \\
\hline \multicolumn{10}{|l|}{2011} \\
\hline Kontrolli & 6,6 & 33 & 51 & 2340 & 117 & 146 & 13 & 21 & 4,7 \\
\hline ALG & 6,6 & 35 & 51 & 2220 & 111 & 144 & 12 & 20 & 16 \\
\hline Ferix-3 & 6,5 & 31 & 44 & 1950 & 116 & 146 & 12 & 16 & 3,0 \\
\hline $\mathrm{SE}$ & - & 2,7 & 5,2 & 144 & 2,5 & 8,5 & 6,51 & 2,27 & 5,50 \\
\hline käs & 0,4 & 0,59 & 0,42 & 0,29 & 0,47 & 0,83 & 0,005 & 0,54 & 0,56 \\
\hline vuosi & 0,07 & 0,42 & 0,47 & 0,14 & 0,04 & $<0,001$ & $<0,001$ & $<0,001$ & 0,83 \\
\hline käs*vuosi & 0,16 & 0,37 & 0,53 & 0,14 & 0,76 & 0,58 & 0,004 & 0,67 & 0,38 \\
\hline
\end{tabular}

$(1: 150){ }^{2)}$ KemWater $^{\mathrm{TM}}$, ALG ${ }^{3)}$ KemWater $^{\mathrm{TM}}$, Ferix-3

Käsittelyt eivät vahingoittaneet kasvustoa, vaikka liuoksen $\mathrm{pH}$ oli alhainen. Käsittelyt eivät vaikuttaneet nurmen P-pitoisuuksiin kumpanakaan vuonna (Taulukko 2). Ensimmäisenä vuonna käsittelyiden jälkeen ALG ja Ferix-3 nostivat kasvien S-pitoisuutta ja sen seurauksena laskivat N:S suhdetta. Toisena vuonna vaikutusta ei havaittu. Ensimmäisenä vuonna Ferix-3 ruutujen sato oli korkeampi kuin muiden ruutujen. Toisena vuonna kemikaaleilla käsiteltyjen ruutujen kasvuston $\mathrm{Na}-$ pitoisuus oli jopa 10-20 kertaa korkeampi kuin ensimmäisenä vuonna.

Ensimmäisenä vuonna valuntaa muodostui vuonna keskimäärin 97 mm/valuntajakso. Kolmen sulatusjakson yhteenlaskettu valunta oli $290 \mathrm{~mm}$ eli noin kolminkertaisesti normaaliin pintavaluntaan verrattuna. Valunta muodostui suhteellisen tasaisesti n. $14 \mathrm{~mm}$ vuorokaudessa. Toisena vuonna valuntaa muodostui kullakin sulatusjaksolla keskimäärin 105 mm. Kokonaisvalunta oli 315 mm. Keskimääräinen vuorokausivalunta oli n. 15 mm. 
Taulukko 2. Kemiallisten käsittelyjen vaikutus kasvustonäytteen kivennäispitoisuuksiin ja kuiva-ainesatoon maan pintaan leikattuna 2010-2011.

\begin{tabular}{|c|c|c|c|c|c|c|c|c|c|}
\hline & $\begin{array}{l}\mathrm{P} \\
\mathrm{g} / \mathrm{kg} \mathrm{ka}\end{array}$ & $\begin{array}{l}\mathrm{Ca} \\
\mathrm{g} / \mathrm{kg} \mathrm{ka}\end{array}$ & $\begin{array}{l}\mathrm{Mg} \\
\mathrm{g} / \mathrm{kg} \mathrm{ka}\end{array}$ & $\begin{array}{l}\mathrm{K} \\
\mathrm{g} / \mathrm{kg} \mathrm{ka}\end{array}$ & $\begin{array}{l}\mathrm{S} \\
\mathrm{g} / \mathrm{ka} \mathrm{ka}\end{array}$ & $\begin{array}{l}\mathrm{Na} \\
\mathrm{g} / \mathrm{kg} \text { ka }\end{array}$ & $\begin{array}{l}\mathrm{N} \\
\mathrm{g} / \mathrm{kg} \mathrm{ka}\end{array}$ & $\begin{array}{l}\mathrm{N}: \mathrm{S} \\
\text { suhde }\end{array}$ & $\begin{array}{l}\text { Kuiva-ainetta } \\
\mathrm{kg} / \mathrm{ha}\end{array}$ \\
\hline \multicolumn{10}{|l|}{2010} \\
\hline Kontrolli & 2,31 & 4,59 & 1,37 & 16,9 & 1,44 & 0,02 & 16,1 & 11,1 & 1730 \\
\hline ALG & 2,78 & 4,13 & 1,28 & 20,4 & 2,81 & 0,02 & 18,3 & 6,55 & 1830 \\
\hline $\begin{array}{l}\text { Ferix-3 } \\
2011\end{array}$ & 2,64 & 3,99 & 1,28 & 19,4 & 2,96 & 0,02 & 18,8 & 6,36 & 2590 \\
\hline Kontrolli & 2,76 & 4,10 & 1,61 & 16,3 & 1,74 & 0,08 & 17,5 & 10,0 & 1450 \\
\hline ALG & 2,54 & 4,05 & 1,54 & 14,7 & 1,59 & 0,27 & 16,5 & 10,4 & 1580 \\
\hline Ferix-3 & 2,48 & 3,71 & 1,37 & 14,8 & 1,47 & 0,44 & 16,0 & 10,9 & 1720 \\
\hline $\mathrm{SE}$ & 0,199 & 0,211 & 0,088 & 1,79 & 0,155 & 0,051 & 1,54 & 0,60 & 143 \\
\hline käs & 0,73 & 0,09 & 0,19 & 0,83 & $<0,001$ & 0,01 & 0,88 & 0,004 & 0,003 \\
\hline vuosi & 0,91 & 0,12 & 0,01 & 0,01 & $<0,001$ & $<0,001$ & 0,38 & $\begin{array}{l}< \\
0,001\end{array}$ & $<0,001$ \\
\hline käs*vuosi & 0,10 & 0,63 & 0,60 & 0,26 & $<0,001$ & 0,01 & 0,33 & $\begin{array}{l}< \\
0,001\end{array}$ & 0,08 \\
\hline
\end{tabular}

2) KemWater $^{\mathrm{TM}}$, ALG ${ }^{2)}$ KemWater $^{\mathrm{TM}}$, Ferix-3

Molemmat kemikaalikäsittelyt vähensivät kontrolliin verrattuna selvästi sekä kokonais- että liukoisen fosforin huuhtoutumista ensimmäisen vuoden aikana kaikilla sulatusjaksoilla, mutta eivät enää seuraavana vuonna (Taulukot 3 ja 4). Ensimmäisenä vuonna vähennys oli lähes sama kaikilla sulatusjaksoilla. Poikkeuksen muodosti vain ensimmäisenä vuonna odottamattoman alhainen liuenneen P:n pitoisuus toisella sulatusjaksolla kaikissa käsittelyissä (Taulukko 4). Sen sijaan kokonaisfosforin pitoisuudessa ei havaittu eroja kyseisellä jaksolla (Taulukko 3). Toisena vuonna liuenneen fosforin määrä väheni kaikissa käsittelyissä sulatusjaksolta toiselle, kun taas kokonaisfosforin määrässä vastaavaa ei havaittu. Koejäsenten välillä ei ollut eroja.

Taulukko 3. Kemiallisten käsittelyiden vaikutus kokonaisfosforin pitoisuuteen lumen sulamisvedessä. Sulatusjakso (jäädytys, lumetus ja sulatus) toistettiin kokeen aikana kolme kertaa kullekin laatalle.

\begin{tabular}{|c|c|c|c|c|c|c|c|c|}
\hline & & \multicolumn{4}{|c|}{ Kokonais- $\mathrm{P} \mathrm{mg} \mathrm{l}^{-1}$} & \multicolumn{3}{|c|}{ P-arvot } \\
\hline Vuosi & Sulatusjakso & Kontrolli & $\mathrm{ALG}^{1)}$ & Ferix-3 ${ }^{2)}$ & $\mathrm{SE}$ & käsittely & $\begin{array}{l}\text { sulatus- } \\
\text { jakso }\end{array}$ & $\begin{array}{l}\text { käsittely* } \\
\text { sulatusjakso }\end{array}$ \\
\hline \multirow[t]{3}{*}{2010} & 1 & 0,54 & 0,25 & 0,25 & 0,046 & 0,001 & 0,15 & $<0,001$ \\
\hline & 2 & 0,41 & 0,26 & 0,29 & & & & \\
\hline & 3 & 0,41 & 0,25 & 0,33 & & & & \\
\hline \multirow[t]{3}{*}{2011} & 1 & 0,56 & 0,60 & 0,59 & 0,050 & 0,84 & 0,002 & 0,70 \\
\hline & 2 & 0,46 & 0,46 & 0,44 & & & & \\
\hline & 3 & 0,53 & 0,56 & 0,48 & & & & \\
\hline
\end{tabular}

Taulukko 4. Kemiallisten käsittelyiden vaikutus liuenneen fosforin pitoisuuteen lumen sulamisvedessä. Sulatusjakso (jäädytys, lumetus ja sulatus) toistettiin kokeen aikana kolme kertaa kullekin laatalle.

\begin{tabular}{|c|c|c|c|c|c|c|c|c|}
\hline \multicolumn{7}{|c|}{ Liuennut $\mathrm{P} \mathrm{mg} \mathrm{l}^{-1}$} & \multicolumn{2}{|l|}{ P-arvot } \\
\hline Vuosi & Sulatusjakso & Kontrolli & $\mathrm{ALG}^{1)}$ & Ferix-3 $3^{2)}$ & SE & käsittely & $\begin{array}{l}\text { sulatus- } \\
\text { jakso }\end{array}$ & $\begin{array}{l}\text { käsittely* } \\
\text { sulatusjakso }\end{array}$ \\
\hline \multirow[t]{3}{*}{2010} & 1 & 0,49 & 0,21 & 0,22 & 0,04 & 0,001 & $<0,001$ & 0,006 \\
\hline & 2 & 0,14 & 0,04 & 0,09 & & & & \\
\hline & 3 & 0,27 & 0,11 & 0,19 & & & & \\
\hline \multirow[t]{3}{*}{2011} & 1 & 0,46 & 0,49 & 0,48 & 0,07 & 0,42 & 0,01 & 0,67 \\
\hline & 2 & 0,40 & 0,41 & 0,35 & & & & \\
\hline & 3 & 0,39 & 0,30 & 0,24 & & & & \\
\hline
\end{tabular}


Kemikaalien rikkipitoisuus näkyy selvästi ensimmäisen vuoden kaikissa sulatusjaksoissa, vaikka vaikutus on suurin ensimmäisellä jaksolla (Taulukko 5). Toisena vuonna valumaveden rikkipitoisuudessa ei ollut eroja käsittelyiden välillä. Valumaveden rauta ja alumiinipitoisuudet olivat alhaiset molempina vuosina. Alumiinipitoisuus vaihteli välillä $0.1-0.11 \mathrm{mg} / \mathrm{l}$ ja rautapitoisuus välillä 0.003-0.03 mg/l. Kemikaalikäsittelyt alensivat valumaveden $\mathrm{pH}$ :ta ensimmäisenä vuonna 0.1 yksikköä (7.4 vs. 7.3, p-arvo 0.02). Toisena vuonna käsittelyillä ei ollut vaikutusta.

Taulukko 5. Kemiallisten käsittelyiden vaikutus rikkipitoisuuteen lumen sulamisvedessä. Sulatusjakso (jäädytys, lumetus ja sulatus) toistettiin kokeen aikana kolme kertaa kullekin laatalle.

\begin{tabular}{|c|c|c|c|c|c|c|c|c|}
\hline & & \multicolumn{3}{|c|}{$\mathrm{S} \mathrm{mg} \mathrm{l}^{-1}$} & \multicolumn{4}{|c|}{ P-arvot } \\
\hline Vuosi & Sulatusjakso & Kontrolli & $\mathrm{ALG}^{1)}$ & Ferix $-3^{2)}$ & $\mathrm{SE}$ & käsittely & $\begin{array}{l}\text { sulatus- } \\
\text { jakso }\end{array}$ & $\begin{array}{l}\text { käsittely* } \\
\text { sulatusjakso }\end{array}$ \\
\hline \multirow[t]{3}{*}{2010} & 1 & 2,1 & 22,8 & 22,3 & 1,63 & $<0,001$ & $<0,001$ & $<0,001$ \\
\hline & 2 & 1,6 & 9,3 & 9,9 & & & & \\
\hline & 3 & 1,1 & 6,3 & 6,2 & & & & \\
\hline \multirow[t]{3}{*}{2011} & 1 & 1,4 & 1,4 & 1,5 & 0,17 & 0,04 & $<0,001$ & 0,94 \\
\hline & 2 & 0,7 & 0,8 & 0,8 & & & & \\
\hline & 3 & 0,7 & 0,9 & 1,0 & & & & \\
\hline
\end{tabular}

\section{Tulosten tarkastelu}

\section{SIMUn toimintaperiaate}

Tässä kokeessa huuhtoumista tutkittiin laboratorio-olosuhteissa pellolta nostetuilla nurmilaatoilla simuloimalla. Pintavalunnan simuloiminen erilaisina variaatioina on melko yleisesti käytetty menetelmä fosforin huuhtoutumisen tutkimuksessa. Useimmiten simuloimiseen on käytetty ns. pakattua valuntalaatikkoa, joissa maa-aines on otettu pellon pintakerroksesta, kuivattu, seulottu, paineltu laatikkoon tiettyyn tiiviyteen ja sadetettu ja käsitelty vasta sitten. Kleinman ym. (2004) tutkimuksessa todettiin kuitenkin, että pakattukin valuntalaatikko on toimiva keino vertailtaessa erilaisia käsittelyitä toisiinsa, vaikka tuloksia ei suoraan voi yleistää peltomittakaavaan.

Simulaattorilla on useita etuja peltomittakaavan tutkimukseen verrattuna. Se on tehokas ja edullinen keino verrata erilaisia käsittelyjä toisiinsa (Hart ym. 2004, Sharpley ja Kleinman 2003). Menetelmä on joustava ja helposti säädeltävissä: sadetus, lumetus, lämpösäteilyn määrä, pintavaluntatason kallistuskulma jne. voidaan säätää vastaamaan haluttuja ympäristöolosuhteita. Pienessä mittakaavassa voidaan testata riskittömästi radikaalejakin huuhtoutumisen vähentämismenetelmiä, joita ei haluta viedä suoraan peltomittakaavan tutkimuslaitteistoille kuten esimerkiksi jäteveden puhdistamolla käytettävät fosforia sitovat kemikaalit, jotka joissain kokeissa ovat jo osoittautuneet erittäin potentiaalisiksi menetelmiksi (Torbert ym. 2005).

Toisaalta kirjallisuudessa on esitetty myös kritiikkiä menetelmää kohtaan: tulosten yleistettävyys on huono pienen pinta-alan takia (Sharpley ja Kleinman 2003), pintavalunnan muodostumismekanismin realistisuus ei vastaa todellisuutta, koska maan huokosrakenne muuttuu ja valuntalaatikon läpäisemätön pohja ohjaa valuntaa enemmän pintavalunnaksi kuin normaaleissa olosuhteissa, kasvipeitteisyys ei vastaa todellisuutta ja kokeen aikana vaikuttavat muut olosuhteisiin liittyvät virhelähteet saattavat sotkea tuloksia pienen mittakaavan takia (Kleinman ym. 2004).

Sen sijaan maalaatan paksuus ( $5 \mathrm{~cm}$ vs $25 \mathrm{~cm}$ ) ei Kleinmanin ym. (2004) mukaan vaikuttanut muodostuneen pintavalunnan määrään eikä fosforipitoisuuteen. Maan kosteus $4 \mathrm{~cm}$ syvyyteen sadetuksen jälkeen oli sama kummassakin käsittelyssä. Myöskään maalajilla (hiesuinen hieta ja hieta) ei ollut merkitystä.

Kleinman ym. (2004) mukaan suurimmat erot pellon ja valuntalaatikon välillä syntyvät maan huokosrakenteen rikkoutumisesta, joka heikentää laatikkoon pakatun maan infiltraatiokykyä häiriintymättömän maahan verrattuna sekä valuntalaatikon kasvipeitteen puuttumisesta, mikä voimistaa sadetuksen vaikutusta suoraan maan pintaan ja paljaan maan eroosioherkkyydestä. SIMUn toimintaperiaate on näiltä osin erilainen: maan pinnasta höylätyssä laatassa säilyvät sekä pintamaan 
huokosrakenne että kasvipeite, joten näiltä osin SIMUn voi olettaa kuvaavan pakattua maalaatikkoa paremmin pintavalunnan todellista syntymekanismia.

Toisaalta koska höylätty nurmilaatta läpäisee vettä luultavasti helpommin kuin pakattu valuntalaatikko, laatan paksuuden merkitys tulee uudelleen arvioitavaksi. Lisäksi luonnonolosuhteissa maa ei lumipeitteen alla jäädy täysin tasaisesti ja läpäisee talven leutojen jaksojen aikana ja kevätsulannan alkaessa jonkin verran vettä ilmatäytteisten makrohuokosten kautta (Sutinen ym. 2008). Infiltraation ja laatan paksuuden merkitystä SIMUn toiminnan kannalta tuleekin jatkossa vielä tarkentaa.

\section{Käsittelyjen vaikutus}

Fosforin huuhtoutuminen pintavalunnassa riippuu mm. pintamaan fosforipitoisuuden, eroosion ja pintaan annetun lannan tai lannoitteen vesiliukoisen fosforin määrästä (Kleinman ym. 2004). Suoraan lannoitteesta peräisin oleva fosfori on todettu merkittäväksi kuormituslähteeksi, sitä enemmän mitä lyhyempi aika lannan tai lannoitteen levittämisen ja sateen aiheuttaman valuntapiikin välillä on (Kleinman ym. 2002). Tässä kokeessa testattiin kemikaalien vaikutusta pintavalunnan fosforipitoisuuteen kevätvalunnassa, kun pintamaassa on korkea fosforipitoisuus.

Kokeessa kemikaalien vaikutus kesti ensimmäisenä vuonna kolme sulatussykliä eli yhteensä noin 315 mm pintakerrosvaluntaa. Tämä ylittää selvästi läheisellä lysimetri- ja pintavaluntakentällä mitatun keskimääräisen pintavalunnan määrän, joka on noin $100 \mathrm{~mm} / \mathrm{v}$. Vastaavasti lysimetrivalunta on noin $150 \mathrm{~mm} / \mathrm{v}$ (Saarijärvi 2008). Koska alueen maalaji on samanlaista, voidaan olettaa, että syksyllä 2011 nostetuilta laatoilta on muodostunut kevään ja kesän 2011 aikana saman verran valuntaa kuin lysimetrikentällä. Näissä laatoissa kemikaalien fosforihuuhtoumaa vähentävää vaikutusta ei kuitenkaan enää havaittu edes ensimmäisellä sulatusjaksolla, vaikka laattojen vuotuinen kokonaisvalunnan määrä jäi pienemmäksi kuin kolmen sulatussyklin yhteenlaskettu valunnan määrä ensimmäisenä vuonna, joissa kaikissa kemikaalien vaikutus oli selvästi havaittavissa.

Annetun määrän (0,2 g Fe / l ja 0,18 g Al / l maata) laskennallinen kapasiteetti (oletuksena että yksi $\mathrm{Fe}^{3+}$ tai $\mathrm{Al}^{3+}$ ioni pidättää yhden $\mathrm{PO}_{4}-\mathrm{P}$-ionin) riittää sitomaan $5 \mathrm{~cm}$ pintakerroksesta $5,5 \mathrm{~g} \mathrm{P}$ (rauta) tai 10,3 g (alumiini) liuennutta $\mathrm{P} / \mathrm{m}^{2}$. Kasvustossa oli molempina syksyinä keskimäärin $0,4 \mathrm{~g} \mathrm{P}$ $/ \mathrm{m}^{2}$. Jäätyminen rikkoo kasvien ja mikrobien solukkoa ja vapauttaa fosforia maanesteeseen ja maan pintakerroksen liuenneen fosforin pitoisuus nousee (Uusi-Kämppä ja Jauhiainen 2010). Kasvustoon sitoutuneen fosforin lisäksi helppoliukoista fosforia oli ylimmässä $5 \mathrm{~cm}$ maakerroksessa laskennallisesti keskimäärin 2,9 g/m $\mathrm{m}^{2}$ eli yhteensä fosforia oli maassa ja kasvustossa 3,3 g/m². Tämä selittää kemikaalien tehokkuutta valumaveden liukoisen fosforin pitoisuuden alentamisessa sekä myös alumiinin rautaa korkeamman vähennysprosentin ensimmäisen talven aikana.

Koska ensimmäisenä vuonna nostetuissa nurmilaatoissa kemikaalien vaikutus pysyi koko talven ajan merkittävänä viikkojen varastoinnista ja suuresta valunnasta huolimatta, voidaan olettaa että vuoden 2011 syksyllä nostetuissa nurmilaatoissa nimenomaan kevään ja kesän olosuhteet maaperässä vaikuttivat kemikaalien toimintaan. Kylmässä ja jäisessä maassa maahiukkasten ja maanesteen kontakti on vähäisempää kuin sulassa maassa ja sekä kemialliset että biologiset reaktiot ovat hitaampia (Williams ym. 2012). Toisaalta jäätyminen edistää fosforin pidättymistä, koska maan jäätyessä maanesteen suolakonsentraatio kasvaa. Kemikaalien sitoessa fosforia maanesteestä, sitä vapautuu vastaavasti oksidien pinnoilta labiileista eli helposti vapautuvista varoista. Näin lisättyjen kemikaalien pidätyskapasiteetti ehti ilmeisesti täyttymään kesän aikana ja vaikutusta ei havaittu enää toisena vuonna. Tämä tukee Schärerin (2007) johtopäätöstä, jonka mukaan lannoittamalla tai muuten korkeaksi noussut maan fosforipitoisuus ei alene lyhytaikaisilla käsittelyillä.

Myös pellolle levitetyn lannan fosforihuuhtoumia on saatu vähennettyä kemiallisilla käsittelyillä. Brennanin ym. (2011) kokeessa parhaiten toimi alumiinisulfaatti, joka vähensi fosforin huuhtoumista $94 \%$ verrattuna käsittelemättömään lietelantakoejäseneen. Torbertin ym. (2005) kokeessa tehokkaimmaksi osoittautui ferrisulfaatti (400 kg/ha) jolla saavutettiin lyhytaikaisesti jopa $100 \%$ reduktio käsittelemättömään koejäseneen verrattuna. Samassa kokeessa kalkki ja kipsi vähensivät liukoisen fosforin huuhtoutumista vain lyhyen hetken sadetusvalunnan alussa, mutta niillä ei ollut vaikutusta huuhtoutuneeseen kokonaismäärään.

Tässä kokeessa nurmilaatoilta huuhtoutuneen veden liuenneen fosforin pitoisuus laski kemikaalikäsittelyiden ansioista $\quad$ ALG-ruuduilla $56-70 \quad \%$ ja $\quad$ Ferix-3 ruuduilla $29-56$ \% 
kontrollikäsittelyyn verrattuna. Uusi-Kämpän ym. (2012) kokeessa liukoisen fosfori väheni 57-80 \% käsittelemättömään koejäseneen verrattuna. Myös Schärerin ym. (2007) kokeessa rauta- ja alumiiniyhdisteet olivat tehokkaita liuennen fosforin määrän vähentämisessä, mutta kuten jo edellä todettiin, vaikutus oli lyhytaikainen.

\section{Johtopäätökset}

Nurmen pintaan kenttäoloissa levitetyt fosforia sitovat Al- ja Fe-pitoiset kemikaalit vähensivät nurmelta tulevan simuloidun pintavalunnan fosforikonsentraatiota selvästi. Alumiiniyhdiste oli rautayhdistettä jonkin verran tehokkaampi. Vaikutus kesti kuitenkin vain yhden talven, mikä saattoi osittain johtua maltillisesta annostuksesta. Toisaalta kemikaalien fosforin huuhtoutumista vähentävä vaikutus on havaittu lyhytaikaiseksi aiemmissakin tutkimuksissa. Käsittelyt eivät vaikuttaneet epäsuotuisasti nurmen kasvuun eivätkä alentaneet helppoliukoisen fosforin pitoisuutta maassa.

\section{Kirjallisuus}

Brennan R.B., O. Fenton, J. Grant and M.G. Healy. 2011a. Impact of chemical amendment of dairy cattle slurry on phosphorus, suspended sediment and metal loss to runoff from a grassland soil. Sci. Total Environ. 409:5111-5118.

Huang, C.Y.L. ja Schulte, E.E. 1985. Digestion of plant tissue for analysis by icp emission spectroscopy. Commun. in Soil Sci. Plant Anal., 16(9): 943-958

Kleinman P.J.A., A.N. Sharpley, B.G. Moyer and G.F. Elwinger. 2002. Effect of mineral and manure phosphorus sources on runoff phosphorus. J. Environ. Qual. 31:2026-2033.

Kleinman P.J.A., A.N. Sharpley, T.L. Veith, R.O. Maguire ja P.A. Vadas. 2004. Evaluation of phosphorus transport in surface runoff from packed soil boxes. J. Environ. Qual. 33:1413-1423. Lehrsch G. 1998. Freeze-thaw cycles increase near-surface aggregate stability. Soil Sci. 163:63-70.

Saarela, I. 1992. A simple diffusion test for soil phosphorus availability. Plant and Soil 147: 115-126.

Saarijärvi, K. 2008. Nitrogen cycling on intensively managed boreal dairy pastures. Agrifood Research Reports, Maa- ja elintarviketalous 134: 71 s. + 4 liitettä. Diss. : Kuopion Yliopisto, 2008.

Saarijärvi, K. ja Virkajärvi, P. 2004. Laitumen fosforikuormitus, tase ja pintavalunta. In: Maataloustieteen Päivät 2004, 12.-13.1.2004 Viikki, Helsinki [: esitelmät ja posterit] / Toim. Anneli Hopponen ja Marketta Rinne. Suomen maataloustieteellisen seuran tiedote 19: 4 p.

Saarijärvi, K. ja Virkajärvi, P. 2010. Surface runoff simulator (SIMU) hastens the research on phosphorus losses from grassland. In: Grassland in a changing world: proceedings of the 23th General Meeting of the European Grassland Federation, Kiel, Germany, august 29th - september 2nd 2010 / Edited by H. Schnyder et al.. European Grassland Federation. p. 78-80.

Sharpley A. and P.J.A. Kleinman. 2003. Effect of rainfall simulator and plot scale on overland flow and phosphorus transport. J. Environ. Qual. 32:2172-2179.

Schärer M., Stamm, C., Vollmer, T., Frossard, E., Oberson, A., Fluehler, H. ja Sinaj S. 2007. Reducing phosphorus losses from over-fertilized grassland soils proves difficult in the short term. Soil use Manage. 23:154-164.

Sutinen R., Hänninen, P. ja Venäläinen, A. 2008. Effect of mild winter events on soil water content beneath snowpack. Cold Reg. Sci. Technol. 51:56-67.

Torbert H., K. King and R. Harmel. 2005. Impact of soil amendments on reducing phosphorus losses from runoff in sod. J. Environ. Qual. 34:1415-1421.

Turtola, E. ja Kemppainen, E. 1998. Nitrogen and phosphorus losses in surface runoff and drainage water after application of slurry and mineral fertilizer to perennial grass ley. Agric. and Food Sci. in Finl. 7: 569-581

Uusi-Kämppä J., Turtola E., Närvänen, A., Jauhiainen L. ja Uusitalo, R. 2012. Phosphorus mitigation during springtime runoff by amendments applied to grassed soil. J. Environ. Qual. 41:420-426.

Uusi-Kämppä J. ja Jauhiainen, L. 2010. Long-term monitoring of buffer zone efficiency under different cultivation techniques in boreal conditions. Agriculture Ecosystems \& Environment 137:75-85.

Vuorinen, J. \& Mäkitie, O. 1955. The method of soil testing in use in Finland. Agrogeological Publications 63:1-44.

Williams M.R., Feyereisen, G.W., Beegle D.B. ja Shannon, R.D. 2012. Soil temperature regulates phosphorus loss from lysimeters following fall and winter manure application. Transactions of the Asabe 55:871-880. 